\title{
The Optimization of Zakat Maal Management in Baubau City
}

\author{
I Wayan Sujana ${ }^{1}$, Samdin Gamsir ${ }^{1} \&$ Ambo Wonua Nusantara ${ }^{1}$ \\ ${ }^{1}$ Economic Study Program, Post-Graduated Halu Oleo University, Southeast Sulawesi \\ Correspondence: I Wayan Sujana, Economic Study Program, Post-Graduated Halu Oleo University, Southeast Sulawesi, \\ Indonesia.
}

Received: December 10, 2018

Accepted: December 31, 2018

Online Published: January 2, 2019

doi:10.11114/bms.v4i4.3923

URL: https://doi.org/10.11114/bms.v4i4.3923

\begin{abstract}
This research aims to know: (1) optimization of the management of zakat maal seen from the aspect of Muzakki, roles, and mustahik on the BAZNAS city of Baubau, (2) Factors that determine the optimization of the management of zakat wealth (Maal) in the city of Baubau (3) The optimization model of zakat wealth (Maal) management in the city of Baubau. The results showed that: (1) Management of zakat wealth (maal) in the city of Baubau is not optimal (2) The factors that determine the optimal management of zakat wealth consist of: (a) supporting aspects of zakat collection and distribution, (b) constraints collection and distribution of zakat, (3) The optimization model of zakat wealth management (maal) in this study is that BAZNAS needs to collaborate with all elements starting from the government, Ministry of Religion, and Scholar so that the management of zakat wealth can be maximized both in collection and distribution efforts. establish good relations with muzakki and mustahik.
\end{abstract}

Keywords: optimization, model, management, Zakat Maal

\section{Introduction}

Zakat in the context of the ummah is one of the potential and very important sources of funds drawn from people who have wealth the specified size limit and the amount of Zakat to be paid based on the type and nature of the source of the wealth. Zakat has an important role in the Islamic economic system because in the Islamic community zakat can be used as a source of funds to create even economic life (Samdin, 2015: 74).

In economic principles of Syari'ah there are several economic instruments to help social interests such as; utilization of Zakat, infaq, and alms funds to finance the welfare of the people. It makes the great potential of increasing the benefits of Zakat to realize the welfare of the Indonesian people as Muslims and is used as an alternative for the Government to implement welfare equality and poverty reduction for every level of society.

The state has the right to force under the law of violence so that the obligations of Zakat are carried out by the Caliph Abu Bakr who fought those who were reluctant to issue Zakat as was done. Law Number 23 of 2011 which specifically regulates about management of zakat explains the importance of increasing the performance of BAZ and LAZ as a professional, trustworthy, trusted amil zakat body and having a clear and planned work program and able to manage zakat optimally so as to improve the quality of life and the lives of mustahik.. The existence of institutions that deal with it well and trustworthily is one of the reasons for the optimal function of Zakat as an instrument of economic equality of the ummah so that they can be trusted to channel their Zakat to the official institution. Starting from the collection of Zakat to the distribution to the rightful people, and this right is the duty of amil Zakat

The results of the research are quite astonishing about the living conditions of Indonesian people in terms of their income and economic income; First, according to Standard Chartered Bank in the book Amil Zakat Standarddization in Indonesia, the Ministry of Religion Republic of Indonesian 2013 said that there were around 4 million well-established people who earned Rp. 240-500 million per year in Indonesia. Second, Credit Suisse Research Institute (Credit Suisse Global Wealth Report 2010) and Merril Lynch Wealth Management, Bank of America and Capgemini (Asia Pacific Wealth Report 2010) state that there are approximately 60 thousand Indonesian billionaires who have a wealth of at least USD 1 Million or Rp. 9 billion, which they call the term high net worth. The results of research from several research institutions are very interesting to follow up, especially to get more detailed data about anyone among the billionaires and millionaires who are categorized as Muslims to be motivated to issue Zakat.

The level of obligatory zakat compliance is positively influenced by public perceptions of the distribution of zakat funds 
carried out by zakat institutions. This means that obligatory zakat will continue to pay zakat in that place if an amil zakat institution distributes zakat funds properly to people who are entitled to receive and not commit misuse of zakat funds. Campaign/socialization and improvement of the quality of zakat services carried out by an organization have a significant effect on someone to pay Zakat at the institution (Ahmad and Wahid; 2005).

Perceptions and compulsory Zakat attitudes that pay Zakat through BAZNAS, from the six attributes used, namely product, place, people, promotion, process, and physical evidence, it is seen that the average level of confidence of the six attributes both muzakki institutions and non-institution muzakki almost have differences which are not too far away. From the calculation of Ao (consumer attitude) as a whole, Fishbein Muzakki Institute's multi-attribute score was 97.37, and the Non-Institution muzakki was 90.41. This shows that overall Muzakki Institutions indeed prefer BAZNAS Institutions to channel their Zakat compared to non-institutional Muzakki. (Shalihati; 2010).

Research conducted by Saad, et al (2009) on the attitude of employers to rules that require employers to pay Zakat through Zakat management organizations. This research was conducted in the Kedah region, Malaysia, and the respondents were entrepreneurs. The results of this study found that employers have different attitudes towards the rules, the attitude is divided into five types, namely: encouraging attitudes, positive attitudes, total rejection attitude, conditional attitude, and conditional rejection attitude. The attitude of encouragement is a form of public acceptance in general regarding the payment of Zakat to Zakat institutions. The phenomena that occur in the lay community regarding understanding and management around the problem of Zakat, it seems that there are still quite diverse.

From the various efforts that have been made by Baubau BAZNAS in 2012-2016, the receipts of Zakat, Infaq and Shodaqoh are as follows: Revenue from total Zakat from 2012 to 2016 shows an increase even though it has not reached the set target of Rp. 2. 490,000,000 (source of BAZNAS in Baubau City), where Zakat Maal occupies the lowest revenue in 2012 of Rp. 33,803,172 and increased in 2017 amounting to Rp. 78,292,000, and the largest revenue is sourced from Zakat fitrah where the income in 2012 is Rp. 1,160,082,572 increased in 2017 amounting to Rp. 2,206,275,750, City of Baubau GRDP (Gross Regional Domestic Product) in 2012-2016 and the potential Zakat of the city of Baubau on the basis of 2000 Constant prices (Rp. Million). The potential of Zakat in Baubau City shows an increasing trend, which in 2012 amounted to Rp. 109.3 billion, increasing in 2013 to Rp. 120.1 billion, in 2014 Rp. 129.7, increasing in 2015 to Rp. 140.9 and 2016 amounting to Rp. 153.5 billion.

The calculation of the estimated Zakat potential above shows that the potential of Zakat in the city of Baubau is very large, which is several times compared to the original regional income wherein 2012 the Baubau City PAD was Rp. 19.5 billion, in 2013 it was Rp. 33.8 billion, in 2014 Rp. 56.05 billion, in 2015 amounting to Rp. 36.4 billion and in 2016 Rp. 44.15 billion (source: BPS City of Baubau). In other words, if the potential of the Zakat can be extracted optimally, then the new source of development funds will be large enough to be used to alleviate the people from poverty. But judging from the realization of Zakat, infaq and sedekah when compared to the estimated potential of Zakat, the ratio of realization to potential is still very small. This shows that the potential of the Zakat is still just potential, has not been optimally explored and empowered.

The Central Statistics Agency noted that in 2016 the number of poor people in Baubau City was 14,290 people, that of the existing 14,290 poor people, only 1,428 were poor or mustahik who received Zakat benefits distributed by BAZNAS in Baubau City. This shows that there is still a difference of around 12,862 poor people who need attention from the government through the management of Zakat which is more optimal at BAZNAS in Baubau City.

Zakat assets (Zakat maal) must be seen as a revolving fund whose use must be directed towards productive business so that the continuity of business carried out in the sector of the people's economy can be established.

\section{The Conception of Zakat}

\subsection{Definition of Zakat}

Zakat according to language (lughat) means: grow, develop, fertility or increase or can also mean cleaning or purifying. In the Qur'an, there are many verses that explain the obligations of the zakat, among others: The word zakat in many definitions is mentioned 30 times in the Qur'an, twenty-seven of which are mentioned together in one verse along with the prayer or Allah mentions the obligation to establish salat with the obligation to pay zakat. The words or designations of Zakat, among others, are mentioned in the letter of al-Baqarah verse 43: "And establish the prayer, pay the zakat and bow down with those who bow".

\subsection{The Previous Research}

El-Din (1986) states that the allocative function of zakat is expressed as a tool or instrument to fight poverty. The pattern of distribution of zakat can give wider impact on economic conditions if not only given in the form of consumer goods and production goods but also in the form of equity which is expected to have a wider impact on economic conditions. 
Beik (2009) Analyze the role of zakat in reducing poverty; case study of dhuafa republika wallet. The results show that zakat is able to reduce the number and percentage of poor families, and reduce the depth and severity of poverty.

Rusli, et al. (2013) analyzed the impact of the provision of productive zakat capital on poverty alleviation in Aceh Utara. Provision of productive zakat in the form of business capital has a positive impact on increasing people's income and reducing the number of poverty in North Aceh Regency.

Wan Sulaiman Bin Wan Yosuff (2008) reviewing the Use of Zakat for the Mustahik. The utilization of zakat funds for human resource development with human concentrations capital long-termwill be more successful compared to shortterm utilization, which only satisfies the desired needs, and most importantly is to avoid misleading zakat expenditures.

Patmawati (2006), Economic role of zakat in reducing income inequality and poverty in selangor. Using the Lorenz Curve and the coefficient of the gini, he found that the bottom 10 percent of the community enjoyed 10 percent of the people's wealth due to zakat. This figure rises from 0.4 percent when the transfer of zakat does not occur. While the top 10 percent of the community enjoyed a wealth of 32 percent or down from 35.97 percent in the previous position. This indicates that the gap between groups can be reduced. He also concluded that zakat was able to reduce the number of poor families, reducing the severity of the severity of poverty.

Shirazi (1996), found that in 1990-1991, 38 percent of households in Pakistan lived below the poverty line. But if the zakat transfer mechanism does not occur, the poverty rate will increase. He also concluded that the poverty gap decreased from 11.2 percent to 8 percent with the presence of voluntary zakat transfer mechanisms.

\section{Research Methods}

\subsection{Specification Research}

In this study the writer will describe how the implementation of zakat management optimally based on Islamic Law and Law Number 23 Year 2011 at Badan Amil Zakat in Baubau city .

\subsection{Research Approach}

This research uses a sociological juridical approach.The juridical side of this study will review the rule of law ie Law No. 23 of 2011 on Zakah Management which will be the basis of the jurisdiction of the Amil Zakat Board of the City of Baubau. And what is meant by a sociological approach is how zakah management is implemented by the Amil Zakat Board of the City of Baubau. AND how the Baubau City Amil Zakat Agency optimizes the management of zakat Mal based on Law No. 23 of 2011 and Islamic Law on Zakat Management, to achieve social welfare of the community.

\subsection{Data Research}

The data source used in this study are: Primary data, obtained from field research. This data will be obtained through informants on certain social situations. Secondary data, obtain from literature to get a theoretical foundation in the form of opinions or writings written laws, sources of Islamic law, in particular, relating to the subject matter, as well as documents, archives, and the other required data.

\subsection{Informants}

Informants in this study are (1) BAZNAS Manager of Baubau City, (2) Muzaki (entrepreneur, Zakat Distributor), (3) Mustahik (who are under construction and who only accept consumptive zakat) Bureaucratic (government) (5) Citizen elements (Elementary Scholars, Professionals and Islamic Community leaders) Religion chosen purposively by determining informants who meet the following criteria: (a) Those who understand and master the problems of zakat management and zakat law, (b) Those who are directly involved in the zakat management activities of Muzaki, Mustahik and especially the Amil Zakat Board of the City of Baubau.

\subsection{Data Collection}

Methods of data collection :

\section{Observation}

This method is done to obtain a general and relatively comprehensive picture of what is included in the problem to be studied.

\section{Interview}

Author interview with Amil Zakat manager Baubau city that is a fundamental question about the management and zakat issues. Then the writer also interviewed Mustahiq and the people who have received assistance from the distribution and utilization program of Mal zakat by the Amil Zakat Board of the City of Baubau. 


\section{Literature of Studi (Library Research)}

Examining the documents and materials related to the problems studied.

\subsection{Instruments of Research}

In this study, writers use various tools to collect data such as cameras, recorders, mobile phones, personal computers, daily diaries and a list of pre-prepared questions.

\subsection{Validation of Data}

In this research the data validation examination used is triangulation. Triangulation is the examination of the validity of data utilizing something else beyond the data for the purpose of checking or as a comparison of the data, (Moleong, 2002:178)

The authors do comparisons of data obtained that are secondary data of the results of the literature study will be compared with the primary data obtained from observations and interviews that match the facts encountered in the field. So that the truth of the obtained data can be trusted and convincing for a conclusion.

\subsection{Data Analysis}

The analysis is conducted indirectly, from the field or empirical facts by way of field fielding, studying, analyzing, interpreting, and drawing conclusions from existing phenomena. Data analysis in qualitative research is done simultaneously with the data collection process. Data analysis in qualitative research is an interactive model, comprising the main components of: Data Collecion, Reduction of Data, Presentation of Data, Withdraw Conclusions or Verification.

\section{Research Results and Discussion}

\subsection{Research Result}

\subsubsection{Overview the Management of Zakat in Baubau City}

The results of the research on the management of zakat made by BAZNAS the town of Baubau refers to the General provisions in the legislation of the Republic of Indonesia Number 23 the year 2011 About the management of Zakat is point 1 includes the activities of planning, implementation, and utilization of zakat. Amil Zakat Nasional Agency (BAZNAS) is an institution that does the management of zakat nationally. Amil Zakat institution (LAZ) is an institution set up by the communities that have the task of assisting the collection, distribution, and utilization of zakat which in practice is responsible to BAZNAS.

The mechanism of management of zakat mail very determines the maximum or whether the process of collecting and distributing. Manager of the zakat should do the mapping and log about potential earnings and income of the zakat, the economy of the community. It aims to know anyone who could be encouraged to take out her awareness of zakat. Distribution of zakat productively to be done through measures that can actually reach the appropriate target. According to Zainur Rahman (2011) there were some paces distributing zakat productively: (1) accurately Logging; (2) rrouping mustahik; (3) the granting of basic training; (4) the giving of zakat funds so that managers should proactively alerting.

The results of research and interviews with informants (BAZNAS) explains that: the mechanism of management of zakat on BAZNAS city of Baubau began by doing charity collection by BAZNAS, UPZ, Bank account, or zakat of property conveyed directly to BAZNAS through the Treasurer. Then verifying the kind of charity that has been collected (zakat fitrah zakat or treasures). Based on observation towards the document management of zakat and the results showed muzakki listed on BAZNAS city of Baubau in the year 2017 that totaled as much as the total number of people with 60,117 acceptance zakat amounted to Rp. 2,209,000,702,- with details of the Zakah money fitrah as much as Rp. 1,804,101,321,-and the zakat fitrah rice 42,126.5 liters. Acceptance of infaq, shadakah amounted to Rp. 315,386,981,meanwhile the acceptance of zakat treasure (maal earnings, maal body, and other maal) which successfully collected as much as Rp. 89. 512,500,-. Of religious obligatory, infaq, sadaqah accumulated and then based on the results of research on the recapitulation of distributing Zakah, shows that the total amount of the distribution of zakat in the year 2017 is Rp. $2,164,640,700$,-with details as follows: distribution of zakat fitrah for mustahik of $80 \%$ amounted to Rp. 1.488.505.260,-, and distribution Unit for Collecting Zakat of mosques and the administration of $20 \%$ amounted to Rp. 400,832,090,-. Distribution Unit for Collecting Charity Infaq Zakat (UPZ) Mosque of 20\% amounted to Rp. 31,716,225,-and distribution to National Bodies Amil Zakat (BAZNAS) of 80\% amounted to Rp. 243,587,125. from the distribution of zakat, infaq and sadaqah then remaining balance amount on record collecting and distributing a recapitulation of zakat, infaq and sadaqah as much as Rp. 41,652,050,-.

Research results in the form of observations against the note BAZNAS regarding the report of receipt of zakat maal from 148 muzakki outsiders to suggest that the year 2017 accumulated as much as Rp. 89. 512,500,-. Quantify the amount of zakat maal collected comes from the payment of zakat of property by Muzakki recorded ranged between Rp. 40,000,- 
until Rp. 5 million,-. From the amount of zakat muzakki treasure (maal) listed as many as 148 people than the researchers took as much as (10) the informant with the magnitude of the amount of zakat of property issued by the respective muzakki between Rp 2 million,-until Rp. 4 million,--

Distribution of zakat maal conducted by their respective Muzakki is different between each other. Zakat owned anyone distributes through existing mosque near his home, channeled into the orphanage and boarding school as well as the BAZNAS which is in the town of Baubau. In fact, there is also a direct distribute zakat muzakki treasure (maal) that issue directly to his family and the poor people who need near his home as well as the existing mustahik in his hometown. For more details of optimization management of zakat maal in Baubau city will be discussed in greater detail into two parts namely the optimization of collection and optimization of distribution as seen from the aspect of Amil zakat, Muzaki, Mustahik, Scholar and Umara.

\subsubsection{Collectional}

Efforts undertaken by the parties (BAZNAS) maximizing the collection of zakat maal was formed the Unit Collecting Zakat (UPZ) in every mosque, government agencies as well as private and some colleges are there in Baubau city. In addition, by submitting the letter contains an appeal to remove the zakat maal after known muzaki has sufficient property nisab and haul. the collection of zakat is also done through book publishing current account number: 82300006721 bank Muammalat in Baubau city, so that people who want to pay zakat maal can directly transmit through the published accounts of the baitul maal appointed by BAZNAS.

Based on the results of the study revealed that the collection of zakat of property conducted informant still passive (waiting for) consciousness muzakki to issue because there has been no maal zakat local regulations regarding collecting zakat of property from those rich (Muzakki).

Aspects of Muzakki

From the results of interviews with informants revealed that they had learned about the treasures that must be removed after Zakat has enough nisab and haul. The informant also calculates its own zakat owned after enough size and issued as much as $2.5 \%$. From the interview also revealed that informants disbursed Zakat not only through BAZNAS, but some is channeled directly to the poor that existed around the House informant, some mosques and religious schools. most charity property directly channeled because assumed that if the whole tithes channeled through BAZNAS lest zakat is not really distributed to the poor in need.

\section{Aspects of Amil}

Amil Zakat Nasional agency city of Baubau in maximizing the collection of tithes from the community is to facilitate the implementation of the collection of zakat BAZNAS then formed the Unit Collecting Zakat (UPZ) which is in charge of collecting and distributing zakat fitrah and Zakat maal totalling 325 Units spread over mosque-the mosque, government agencies, private agencies as well as several colleges that existed in the town of Baubau. The Agency is also Implementing Agencies forming Amil consisting of five (5) fields one Field is the collection of tithes, where members of collecting zakat consist of 5 people who each act as coordinators and members. The adoption of the implementing agency management of coordinating the collection of tithes was made based on the decision letter of the Chairman of the BAZNAS. The number of managers (Amil) working full time doesn't exist, no halftime, have an average education level is already 1, Strata trainingthe training management of zakat by BAZNAS the province followed by a representative of the BAZNAS city of Baubau.

\section{Aspect of Mustahik}

Research results revealed that Baznas has no real data mustahik and has no data mustahik the built Baznas, so it is very difficult to know mustahik who has experienced a rise in status to muzakki on five (5) years. This is apparent from the number of mustahik that tend to follow the increase in the amount of zakat collected. Development of the number of mustahik also fluctuate recorded in Baubau Town Baznas of the year 2015-2018 as follows: the year 2015 mustahik totaled 6,444 people, experiencing the considerable Year 2016 increases with the number of 8,729 people, as much as in the year 2017 the number of mustahik has decreased back to 6,421 people, and in 2018 increase be 9,142 people. Although the number of data mustahiq have cycles with fluctuating trends, the results of the note distribution show that the status of the mustahik recipient of zakat is poor. regarding the data mustahik in baznas has the characteristics of a homogeneous, then the researchers take mustahik as an informant with the criteria: who has a business and who is still actively working.

\section{Aspect of Scholar}

The results of the research and interviews to some informants (scholars) agreed that the collection of zakat maal which afdal according the Shari'a Islam through Amil who slighted the Government was BAZNAS the town of Baubau. and agreed that the zakat maal to the collection agency then optimal amil zakat must take and pick from a rich people's wealth has been quite nisab and haul. 


\section{Aspect of Umara}

The results of research and interviews with informants (Umara) revealed that the policies and regulations issued by the Government to support the collection of zakat that is issued a Decree (DECREE) of Baubau Mayor's stewardship of the city BAZNAS 2015-2020 period of Baubau, stewardship as a commitment to the implementation of the collection of tithes assertiveness according management of zakat laws No. 23 of the year 2011. While the proposed draft regulation is studied the management of the proposed zakat of BAZNAS Southeast Sulawesi province for later if allowed will be in proposing to PARLIAMENT the city of Baubau to be local regulations of the city of Baubau.

\subsubsection{Distributing of Zakat Maal}

Research results and observations against the Baznas unfold where distribution and plan on logging by following a pattern that has been stated in a standard Operational Procedure (SOP) which was formulated earlier by Baznas city of Baubau. Distribution and logging zakat begins with a plan by the Chief Baznas, then the Secretary prepared a concept of distribution of zakat, then commissioned the executor prepares the materials distribution, then the Unit Collecting Zakat (UPZ) carry out the distribution of zakat maal. Distribution of the results is done the Unit Collecting Zakat in the town of Baubau then executing draft results distribution.

Aspect of Muzakki

The results of research and interviews with informants (muzakki) revealed that the distribution of zakat maal conducted by their respective Muzakki is different between each other. Zakat owned anyone distribution through existing mosque near his home, channeled into the orphanage and boarding school as well as the BAZNAS which is in the town of Baubau. In fact, there is also a direct distribute zakat muzakki treasure (maal) that issue directly to his family and the poor people who need near his home as well as the existing mustahik in his hometown.

\section{Aspect of Amil}

Management of zakat maal in addition to the economic empowerment of underprivileged communities, zakat is also distributed to the community including social activities to conduct mass circumcision, providing assistance to education funds community, including setting the infaq Rp. 5000, in maximizing inhibit the zakat.

Channeling zakat of property in economics by Baznas distributed to productive businesses such as small traders, where funds are provided in the form of funds for the results. As for the charity fund is given no accompaniment from the BAZNAS so to mustahik that the mandate will be provided with a refund for the result, because in the same distribution before most of the funds channeled. For more productive effort that does not come back, so the funds provided to a halt on the first productive endeavor without scrolling to the next productive effort.

\section{Aspect of Scholars}

The results of the interviews with informants (scholars) agreed that the zakat maal afdhalnya a place to channel or channel it fits the Sharia explained that the "zakat maal became part of the obligations of the individuals or groups who have sufficient standard nisab and haul must be issued. Place of the issue the zakat of property propositions should fit through the institution of Amil zakat which is appointed by the Government because zakat is part of government power which if according to the law the Government designated place is BAZNAS.

\section{Aspect of Umara}

The results of research and interviews with informants (Umara) explained that an outline of the purpose of the legislation of the Republic of Indonesia Number 23 year 2011 About the management of Zakat is poverty reduction and equitable income, where the treasure (zakat Maal) collected should be distributed to 8 asnaf according to the Qur'an it At-Tawba: Poor (50\%), Amil (2.5\%), converts (6\%), Owe (3.5\%), Ibn sabil (\%), Economic/Productive Fisabilillah (10\%). As a non structural Institutions in order to facilitate the work of the Agency's management Amil Zakat, the City Government should provide a regular fee to Baubau Amil, so BAZNAS do not take 2.5\% of the zakat maal collected for fees/honoraria Amil, so the Fund distributed zakat to the poor will be more. The results of the interviews with informants (Umara) also revealed that the presence of a less public confidence (trust) against BAZNAS this requires the existence of political government policies taken to address those problems.

\subsubsection{Factors That Determine Optimization Management of Zakat}

Management of zakat maal can run optimally if refers to the Act of charity management and management are conducted in accordance with the Islamic Shari'a. The fuqaha agreed that compulsory zakat was issued soon after the entire terms are met, either the nisab, haul, collected by Baznas, distributed to eligible, as well as others. This opinion said by Hanafi that whosoever shall be obliged to issue the zakat and was able to remove it, he should not be put off.

When the management of zakat made by Amil with good management this will certainly have an impact on optimal zakat 
of property maintained by the BAZNAS both in the collection of muzakki, distribution for the poor, and empowerment for increase the dependence of the community of mustahik became muzakki as appropriate management of zakat by law.

\section{Awareness of Muzakki}

The level of awareness in paying zakaah muzakki of Informants is large enough, it unfolds with the understanding that Zakah should be $2.5 \%$ of the issued property owned because it is the command of God to clean of property owned and later can be safaat later in the hereafter. This level of awareness is also shown by distributing Zakat on Baznas official institutions although there are also distribute it directly to Mustahik. The other thing is that the zakat treasure (maal) that size don't have to wait for Ramadan issued but can at any time after reaching the treasure nisab and haul.

Mustahik

The results of research and interviews with informants (Mustahik) revealed that the recipient charity treasure (maal) usually in domination by the poor, widows, are more dominant in the form of zakat consumerist, although based on an interview with Baznas Manager transmitted also to the eight other Asnaf, where the dominance of the recipient charity treasure including laborers, street vendors, and some even just waiting for compassion and a helping hand from others

Distribution of zakat in the amil zakat Agency received from the usually more widely used for activity that is consumptive than businesses that are productive. The limitation fund charity treasure (maal) accumulated impact yet of the existence of coaching specifically for Mustahik by amil.

Amil

The results of research and interviews with informants explained that yet the existence of accurate data from Baznas about the number of recipient mustahik zakat distribution resulted in a sometimes inappropriate target. It is based on observations of Baznas documents show that there have been no data mustahik potential recipients of Zakah. Zakat treasure (maal) also sometimes not right on target, which is supposed to be distributed to productive efforts, switching to a distribution that is consumerist. The other thing is the presence of mustahik has not been built or that while trained for productive business development they have. Zakah is distributed only on request neighborhood, where each neighborhood given only part of a total of 10 people are poor, without mustahik the evaluation of the Baznas.

Management of the zakat has not supported the existence of clear and binding rules of local governments towards the management of zakat maal resulted in a caution for the BAZNAS in optimizing the collection of alms from the public (Muzakki). Amil does not yet have the assertiveness to pick up zakat treasure that has enough nisab and haul owned by the community. Baznas should be down fetched directly to maal Muzaki zakat does not have the strength and courage to do so just wait.

Efforts have been made Baznas to provide insight into the importance of removing the zakat of property owned as efforts to improve the reception of zakat maal, through socialization to society through lectures-lectures in The mosque, as well as inviting the community provide an advisory-an Advisory about the importance of the role of zakat in tackling poverty maal and equitable income.

The Role of The Scholar

The role of the clergy is very important in providing an understanding and motivation so that it can provide the impetus for Amil to increase resources that are owned either through education or training-related training in the management of zakat. In practice, the payment of zakat treasure (maal) many societies is mistaken where the treasure that is issued in the form of alms in deem as zakat treasure (maal). Not the least of which is in the Amil mosque can't tell which zakat alms, infaq, and treasures.

Amil professionalism in doing their job humanely when supported by rules or supercede that can serve as guidelines in taking zakat of property to maximize your collection so as to maximize the distribution of in the framework of poverty reduction and equitable revenue as the purpose of the legislation of the Republic of Indonesia No. 23 years 2011, about the management of zakat.

\section{The Role of Umara}

So far there has been no special regulations issued in favor of the optimizing collection, distribution as well as the management of zakat by local governments in the form of Change or other policies. In the management of the Fund made reference that zakat is the legislation of the Republic of Indonesia No. 23 of the year 2011. So Baznas in the collection of tithes did not have the courage to take by force a treasure of rich people who have enough nisab and haul. Distribution of zakat Baznas has done yet uneven and unfair in accordance with usebility, this is due to the presence of concrete data yet on the number of mustahik in the Baznas town of baubau. Where the distribution of zakat only upon request from the village. 
4.1.5 The Findings of Factors That Determine the Optimisation of the Management of Zakat

\subsubsection{Aspects of Collecting}

The Unit Collecting Zakat (UPZ)

The results of research and interviews with informants (Baznas) revealed that in order to facilitate the collection of zakat (maal) by Baznas as well as make it easier for rich people (muzakki) transmit the zakat on own then BAZNAS have formed units Collecting Zakat (UPZ) spread in some places in the town of Baubau.

\section{Constraint}

1. The community's understanding of the constraints still traditional

Research results and observations showed the existence of a presumption of informants (Muzakki) which considers that zakat is more reward if and until afdal performed directly to the mustahik (the poor) that need.

2. Government Regulation

Interview informant with the results of the (Government) shows that yet the existence of a policy or PERDA (Regional Regulation) related management of zakat.

3. The lack of public confidence

The result of extensive research and interviews with informants (Muzakki) and the informant (religious figures and community leaders) show that a lack of public confidence with regard to the condition of the level of integrity and honesty apparatus the Government is still low. The muzakki still doubt the behaviours and mental apparatus. This is proven by the large number of cases of corruption.

\section{Professional Baznas}

Results of research and interviews with informants (Amil Agency) as well as Informants Muzakki and religious figures indicate that no professional Baznas in the management of zakat treasure (maal), when caretaker of the Baznas there is no all of them run basic tasks and functions, this is due to, among others:Not all administrators involved in collecting zakat Baznas treasure (maal) because the pain permanent, because it is not involved, as well as a few people sysops are still active doubles as a civil State Apparatus, Administrative management of zakat treasure (maal) good collection or pendistribusiannya not trnsparansi, In the present collection Unitcollecting Zakat (UPZ) Zakat collected treasures have not been separated between the zakat alms, infaq and treasures.

Lack coordination of Baznas

The management of zakat of property has not been fullest due yet terpentarisirnya well as a rich man who is muzakki issued zakat, as well as statements from religious figures that administrators no longer need to be energetic Baznas in evaluation and on fill with the younger generation who understand more about management of zakat.

\subsubsection{Aspect of Distribution}

The obligatory Zakat was distributed to mustahik in accordance with the Islamic Shari'a, as well as on article 25 of the Constitution of the Republic of Indonesia Number 23 of the year 2011, As for the supporting factors include: distribution of zakat is right on target, the potential mustahik, a fair and equitable Distribution and constraints, empowerment efforts productive, zakat is not yet appropriate to the needs, the lack of

\subsubsection{Model Optimization Of Zakat Maal Collecting}

Model collecting zakat of property to optimize the collection of zakat of property in the framework of poverty reduction and equitable income, then the maximum role required of all elements of the Agency's good government as well as scholars, Amil in fostering Muzakki belief against the body of the Amil zakat. Baznas as a representative of the Government of the need to improve the management of Amil in both Transparent and openness, thus optimizing the collection realised, provide Direction and maximum service, has a level of integrity and honesty that high skills and capacity management (planning, execution) in a take or pick up a property in charity have muzakki.

\subsubsection{Model Optimization The Distribution of Zakat Maal}

The model of the distribution of zakat Agency Amil zakat of property manager implementers as so in the distribution to the right so that it is able to alleviate poverty and increase equity income. To enhance the status of the mustahik be muzakki Baznas need to have a clear program especially related to the distribution of zakat of property in the form of productive effort. Besides honesty and knowledge administrators in the management of zakat is very major, so hacking funds zakat or alms for the purpose of misappropriation of funds outside mustahik empowerment can be avoided. It is desirable for the sake of Amil professionalism its optimal management of the Fund to charity, especially not in Amil and 
professionalism of Office administrators with government employees or private. The potential of zakat of property needs to be owned by Amil Zakat zakat funds planning so that it is clearly the place to be distributed.

\subsection{Discussion}

\subsubsection{The Collection of Zakat Maal Based on Syariah}

The results of the research and the findings of factors optimization aspects of the collection shows that Islamic law and legislation management of zakat is not yet fully applied, whereby: "lack of awareness or understanding of the people who are still traditional" in where Informants Muzakki still channeling zakat of property which is quite nisabnya directly to mustahik (the poor) who need because consider that zakat is more afdal and to reward, so channeling zakat which is done directly by the Muzakki (rich people) against the poor will have an impact on (1) the difficulty of knowing whether the zakat which is transmitted directly by Muzakki is zakat treasure (maal) or only form of infaq or alms. (2) the existence of a mistaken understanding of the community that some people assume that any treasure that is transmitted either through a mosque or channeled directly to the poor was considered as zakat of property. Though called zakat treasure (maal) when using the gold standard i.e. 95 grams and issued as much as $2.5 \%$. or property owned quite a year and have come to nisab and shall be calculated in advance, so zakaah transmitted cannot be identified whether the zakat or alms, infaq treasures. Government Regulation, not to the existence of a policy or change the management of zakat, zakat maal collection by their very nature are still waiting for Baznas.

The results of research and interviews with informants (religious figures and community leaders), as well as informants (cleric) revealed that the Agency Amil Zakat Baubau Town doesn't involve them either give the training, motivation directly related discourses, lectures management of zakat treasure (maal) either the collection or distribution .

\subsubsection{Distributing of Zakat Based on Islamic Syariah}

In the distribution of wealth zakat treasure (maal) that has been collected is to be transmitted or distributed to Poor, poor distributed by Baznas in the form of efforts that is producing such as small traders, five feet where funds are provided in the form of funds for the results. As for the given zakat funds there needs to be a companion of the BAZNAS so to musta hit that the mandate will be provided with a refund for the results, but most of the funds for distributing productive business more no back, so the funds provided to a halt on the first productive endeavour without scrolling to the next productive effort.

\subsubsection{Professionalism of Amil Zakat In Zakat Maal Management}

Management zakat Maal professionally requires a skilled workforce, mastering the problems relating to zakat, full of dedication, honest and trustful sorely needed in the system professional management of zakat. Saefuddin firmly in Samdin (2015:151) says that "to manage or develop the charity, we must have leadership potential that is authoritative, influential and have authority in the muster, distribute and utilize Zakat for target audience based on the Sharia "

Results management optimization factors zakat treasure (maal) shows that yet Baznas Professional running optimally, where the number of Trustees of the existing Baznas not everything is running the basic tasks and functions.

The lack of public confidence against BAZNAS, it is related to the condition of the level of integrity and honesty of the Government apparatus is still low. The muzakki still doubt the behaviors and mental apparatus. This is proven by a large number of cases of corruption in the country.

\subsubsection{Model Optimization of the Management of Zakat Maal in the Town of Baubau.}

Management of zakat maal must manage by Amil Zakat. The skills and abilities of the management body of the Amil well in planning, implementation and evaluation in the collection, distribution and utilization exactly will encourage optimal realization of the collection. Distribution of zakat can be optimized if the whole potential of the zakat collected treasures in baznas channeled the right on target. As well as empowerment charity treasure indeed preferred to productive efforts. Distribution of zakat funds to productive efforts expected to make mustahik more independent, as well as improve status mustahik be muzakki. The role of related government policies in deducing and facilities provided in optimizing the performance of BAZNAS. The role of the ulama as motivators will encourage awareness Muzakki to remove excess property, as well as the example of both religious and community leaders will speed up the management of an existing charity so that poverty can be overcome in order the creation of equitable distribution of income.

\section{Conclusion and Suggestion}

\subsection{Conclusion}

From the results of data, the collection of reality (the phenomenon) description, analysis, and synthesis, then drawn a conclusion as follows:

1. Management of zakat treasure (maal) according to Act No. 23 of the year 2011 about the management of the charity 
include the collection, distribution, and utilization of zakat is seen from the aspect of the role of institutions, and Mustahik Muzaki aspects as follows:

a. Management of the zakat from the aspect of the role of the institutions of the amil zakat Collection that is done by amil zakat is not optimal due to the collection of zakat treasure (maal) still waiting Muzaki who came carrying zakat of property belonging to the Office BAZNAS, Amil does not yet have grounding/courage to take directly from the rich people (Muzakki) against zakat maal that have enough nisab and haul.

Distribution of zakat is done by Amil Zakat occurred in the community more dominated by way of distributing Zakah in consumerist distributing zakat, in short just merely fulfill the obligations as a Muslim without oriented the desire to extend the benefit of the charity itself. Islamic thinkers recommend that zakat was distributed by way of shifting and distribution patterns in consumerist to distributing productively and investatif. Model of Distributing Zakah Consumerist just right if done in an urgent condition, i.e. at the moment impossible requires problem-solving and can't wait much longer. Muzakki.

b. Management of zakat Muzakki aspect of that low levels of awareness about fulfilling the obligation of zakat in

c. Management of zakat treasure (maal) aspects of Mustahik that Fits the Quran surat At-Tawba (9): 60: which says: Behold Mustahiq may take the form of individuals or institutions. As for the charity recipient groups the eight (8) asnafh consists of 1) Belongs; 2 Poor); 3) Amil; 4) Reverts; 5) freeing Slaves or Slave; 6) people owe (al-gharin); 7) Sabilillah (struggle in the way of God) 8) Ibn Sabil (en route)

2. Factors that influence has not been optimal management of zakat treasure (maal) either in the review of aspects of gathering, distributing or utilization, among others: a. low levels of awareness of Mustahik in fulfilling our obligation of zakat.

a. The existence of trust from the community that transmits it self directly to charity they will spend more to target poor people got the right to receive and to reward rather than channeled through bodies of Amil Zakat. This is due to the low level of trust the muzakki against Manager zakat, both originating from the community or the Government.

b. Oversight is not optimal is done by taking action against BAZNAS UPZ (Unit-collecting Zakat) which is in the town of Baubau, in which BAZNAS are just waiting for a report from the charity management units that exist under the control of the BAZNAS.

c. Utilization of zakat Maal to productive efforts, still less was not clear, and where the user funds to productive efforts are given full trust to manage the funds that are given without audit the Fund by BAZNAS

d. Lack of coordination between National Agencies Amil zakat (BAZNAS), the Indonesia Ulema (MUI), and Government (particularly the Ministry of religion) so that gave birth to the management of the trust.

e. The Government of the existence of the city Yet Baubau on managing zakat maal, resulted in suboptimal work BAZNAS in an attempt to bind/force the MUZAKKI to issue the zakat has been to nishab and haul.

f. Management skills and abilities to manage a large organization has not been so developed among administrators zakat. This was revealed from the Administration that is not transparent, as the data required by the public both about the potential of the zakat, the amount of data the community as Muzaki, the potential of the poor as a recipient charity mustahik and reports on the management of the zakat have not response well.

3. Optimization model of the zakat maal management

Practically, can be done through courses, training, daakwah every kutbah, and lectures-lectures by scholars and more importantly is to be supported by the Government and the legislature.

a. Understanding of zakat

An understanding of the meaning of charity tasks in running the amil must understand very well what the charity either by language as well as about substance. Zakat is obligatory to purify oneself of possessions pulled out and treasure.

The purpose of zakat as a mandatory command from God Almighty contained in the Scriptures of the Quran has lofty goals for Muzakki (who issued the zakat) or for Mustahik (which receive zakat). zakaah is prescribed by God Almighty through the intermediary of his Messenger Muhammad who preach that the purpose of tithe it besides clean themselves and property also to prosper them - those less fortunate (mustahik).

Benefits of zakat in addition to prosper the people, help the needy, lighten the load that he owes more beneficial to reduce hatred of people who are helpless or incapable, so the bias menciftakan zakat a lull in the social life of the community environment, as well as enhance the harmonious relationship and kinship, because it would be sure needs a distributed from the zakat fund. An amil must also understand the meaning of the nisab, haul and levels in the dimensions of zakat. Understand the various types of property that must be pay out it is also important to be able to give an explanation to 
every people who wants to issue the zakat charity.

Understanding Amil zakat calculations over how very crucial, Target recipients of Zakat which must be understood in order to increase the trust of amil muzakki against amil i.e. targets or groups of recipients of Zakah are 8 (eight asnafh), namely: 1) Belongs; 2 poor); 3) Amil; 4) Reverts; 5) the freeing of a slave; 6) people owe (Alghari); 7) Sabilillah (struggle in the way of God); 8) Ibn sabil (on the way).

\section{b. Functions and responsibilities of the Amil Zakat}

Every amil should understand its role as amil because they constitute a factor or actor is important in supporting the success of management of zakat. The role that should be run in the task of Amil among others are: Provide guidance to the public about the importance of zakat, Arouse the people, Remind, Give a reprimand for the people who do not fulfill zakat.

\section{c. Role of The Amil zakat}

In addition to understanding the role of amil, then more importantly is how the Amil understands her responsibilities and functions as Amil. The functions and duties set out in this case is: Identify the citizens affected by the compulsory zakat, Set the criteria that the compulsory zakat issued, Set the schedule for the payment of zakat for each payer of Zakah (mustahik), Calculate your zakat, Identify citizens who are entitled to receive zakat, Distribute zakat in accordance with the level of his needs.

\subsection{Suggestions}

With reference to the conclusions and implications of the research, the researcher submits the following suggestions:

1. To solve the problem above, then the most effective solution is we refer to the book of Allah and the Hadith of the Messenger. Among others, the word of God: "Take charity from their property; with the charity that you cleanse and purify them, and pray for them. Behold him because it's (being in the heart of the soul for them. And God heard again know "(QS. At-Tawba: 103)

2. The need for Government's courage in doing the collecting zakat treasure (maal), through local regulations binding so that the zakat of property can be taken by force either sincere or not sincere.

3. Management of zakat by Muzaki who pay or submit directly Zakat to the poor justified in Islam, but to maintain the integrity and not merging muzakki and mustahik to eliminate the gap between giving (person's rich) and the receiver (the poor) that can degrade the dignity and her dignity, it will be more and more noble if afdal zakat treasure (maal) submitted via BAZNAS or LAZ, relic Muzakki domiciled, later BAZNAS party and the LAZ will distribute to the right, so that there is data synchronization, zakat, coordination and evaluation of objects that are entitled to receive zakat. Thus there is no longer a collection of poor around the House at the time muzakki pay zakat.

4. Because the management of zakat of property made by BAZNAS nature still independent, mostly in the socializing only rely on lectures in the mosque when the month of Ramadan, it certainly not touches all parties especially the agencies, Muzakki rich don't go to the mosque, then it is recommended that BAZNAS is working with all parties such as MUI (assemblies of scholars of Indonesia), the Ministry of Religion as the representative of the Government so that there is harmony in the planning, management (empowerment) and the cover answers in order to optimize the role of zakat in reducing poor to prosper them.

\section{References}

Al-Qur'an, Ahmad, S. H., Wahid, D., \& Mohammad, A. (2005). Penswastaan zakat dan kesannya terhadap pembayaran secara formal di Malaysia. Kumpulan kajian ekonomi dan Keuangan Islam Pusat Pengajian ekonomi, UKM.

Beik, I. S. (2009). Analisis Peran Zakat Dalam Mengurangi Kemiskinan Studi Kasus Dompet Dhuafa, Republik . Jakarta. Diperoleh dari : www.imz.or.id

Capgemini, \& Merrill, L. (2010). Asia-Pacific Wealth Report. Diperoleh dari: https://www.capgemini.com

Credit Suisse Research Institute. (2010). Throught Leadership From Credit Suisse Research and The World's foremost Experts. Global Wealth Databook.

El-Din, S. I. T. (1986). Allocative and Stabilizing Functions of Zakat in an Economy. Journal of Islamic Banking and Finance, 3(4).

Kementrian Agama Republik Indonesia, Direktorat Jenderal Bimbingan Masyarakat Islam, Direktorat Pemberdayaan Zakat, 2013. Standarisasi Amil Zakat di Indonesia.

Lexy, J. M. (2002). Metodologi Penelitian Kualitatif. PT. Remadja Rosdakarya: Bandung.

Patmawati.(2006). Economic Role of Zakat in Reducing Income Inequality and Poverty in Selangor. PhD Dissertation. 
Universiti Putra Malaya, Selangor.

Rahman, Z. (2011). Optimalisasi Distribusi Zakat dalam

http://pemudagenius.blogspot.com/2017/05/optimalisasi-distribusi-zakat-html

Rusli, D. (2013). Analisis Dampak Pemberian Modal Zakat Produktif Terhadap Pengentasan Kemiskinan Di Kab. Aceh Utara.Jurnal Imu Ekonomi Pascasarjana Universitas Syiah Kuala, 1(1).

Saad, R. A., Idris, K. M., \& Dan, Z. B. (2009). Peraturan Pembayaran Zakat kepada Istitusi Zakat: Sikap peniaga dan kesannya terhadap gelagat pembayaran zakat perniagaan. Jurnal Syariah, 17, 607-630.

Samdin. (2015). Teori Motivasi Berzakat (Kajian Manfaat Ekonomi, Sosial, dan Dorongan Kelembagaan). Cetakan Pertama. AA-DZ Grafika : Kendari

Shalihati, F. (2010). Analisis Persepsi dan Sikap Muzakki terhadap Badan Amil Zakat Nasional di Kota Jakarta (Tesis). Bogor. Manajemen dan Bisnis, Institut Pertanian Bogor.

Shirazi, N. S. (1996). An Analysis of Pakistan's Poverty Problem and Its Alleviation through Infaq. PhD Dissertation. International Islamic University, Islamabad.

Undang-Undang Nomor 23 Tahun 2011. Tentang Pengelolaan Zakat.

Wan Sulaiman Bin Wan Yusoff. (2008). Modern Approach Of Zakat As An Economic And Sosial Instrument For Poverty Alleviation And Stability Of Ummah.Jurnal Ekonomi dan Studi Pembangunan, 9(1), 105-118.

\section{Copyrights}

Copyright for this article is retained by the author(s), with first publication rights granted to the journal.

This is an open-access article distributed under the terms and conditions of the Creative Commons Attribution license which permits unrestricted use, distribution, and reproduction in any medium, provided the original work is properly cited. 